\title{
The Factors Affecting Religious Development in the Context of Religious Education in Turkey
}

\author{
Muhammet Mustafa Bayraktar \\ Ministry of National Education (MEB), Ankara, Turkey
}

\begin{abstract}
In this paper, the dimensions of religious development in the context of religious education in Turkey were tried to be revealed. In the process of religious development, there are local and cultural factors as well as universal dimensions. In the last 50 years, many scholars made both theoretical and practical studies on religious development. These studies were criticized both for the outcomes and for the methods that provided these results and they were criticised for the fact that they did not consider cultural and social structures and religious pluralism in the sample groups. In this context, it was tried to make a general ranking and evaluation of the processes affecting religious development in Turkey in the study.
\end{abstract}

Keywords: religious education, faith development, religious development, religious thought, religiosity

\section{Introduction}

It can be said that religious development is a concept referring to subjective and objective situations that the individual experiences in the process of his/her religiosity intellectually, emotionally, and behaviorally. When human life is considered, the dimensions of religious development is accepted as a natural fact in terms of the periods and processes passed through. At the same time, it should not be ignored that religious development has a dynamic structure.

Religious development was also studied in the psychology of religion and sociology of religion in Turkey in reference to some variables. Religious development has to be aproached in the context of religious education and continuously evaluated with an interdisciplinary understanding. Because religious development is closely related to the science of religious education, the information obtained in the field of religious development affects religious education practices. The more religious education is important for some families and institutions, the more it is important that this education is transferred in a context and process that the individual can embrace.

How do religious thought, religious feeling, and religiosity begin? Which directions does it develop in? What are the bases of religious life? What kind of ranking and explanation can be made about the processes affecting religious development in the context of religious education? What are the variables or elements in religious development? What dimensions does religious development show itself in? Factors affecting religious development in Turkey were tried to be explained briefly around these questions. Knowing these factors is very important to ensure that the religious education to be planned and carried out is positive and healthy. Thus, it is expected that the work contributes to the works done in religious life, religiosity, and religious development.

Muhammet Mustafa Bayraktar, Ph.D., teacher, Ministry of National Education (MEB). 


\section{Religious Ability}

Some of the Western researchers associate children to an empty plate in terms of faith. At the same time, some of these researchers consider children as sinners in terms of faith, too (Peker, 2003; Yap1c1, 2016). The prophet Muhammad (pbuh) (632) summarized the influence of the religious ability and the environment on the personality and attitudes of the child in the hadith as "No babe is born but upon fitrat (natural instinct). It is his/her parents who make him/her a Jew, a Christian, or a Magian." It is accepted in the studies of religious education in Turkey that children come to the world with a tendency to the right, to the good, to the clear mind, to the social conscience, to be inclined to Islam, and to believe in the existence and oneness of Allah in the frame of the hadith on fitrat of the prophet of Islam (Okumuşlar, 2002). Scientific researches on religious feelings, the birth, and development of faith done by many psychologists (Yavuz, 1987; Peker, 2003; Kayıkl1k, 2003; Eșel, 2009; Hökelekl1, 2010) showed that children came to the world as spiritually talented and ready for the external religious influences and experiences.

The fitrat is to be inclined to the good and to the blessed innately, but it can not be considered to be sufficient on religious development alone. Because human being is surrounded by a network of relationships and interactions shaping themselves since birth, it is possible to list the other factors affecting religious development as follows.

\section{Family}

One of the factors affecting religious development is family. The reason of the search for clues about religious development in the family is that the family has a network of relationships and interactions influencing and determining the formation of the personality and behaviors, attitudes and perceptions, and social skills and judgments. The home is defined as an acculturation environment (Usta, 2001, p. 70) in which the child's personality is shaped, his/her emotions are directed (Bayraktar, 1997, p. 112), attitudes and habits are gained, traditional forms of behavior, rules of etiquette, cultural heritage, moral judgments, and values are transmitted (Ayhan, 1995, p. 47). Because of these functions, the family is regarded as a basic social unit (Günay, 2002, p. 239), institution (Ay, 1999, p. 126), and system based on biological, psychological, legal, moral, economic, cultural, and religious ties.

The religious structure of the family, which is the most important source and model of religious life, religious behaviors and practices is the fundamental in awakening of the child's religious feelings, shaping of religious beliefs, acquiring religious habits, practices, and experiences (Yıldırım, 1997, p. 119; İmamoğlu, 2001, p. 192). There are religious motifs that the family teaches to the child in the course of his/her religiosity.

Many psychologists and sociologists indicated the links between family and religion (Altıntaş, 1981, p. 266). Many researches and observations also have the same conclusion that family relationships are the most influential factors in the formation of religious beliefs and attitudes in early childhood period (Hökelekl1, 2010, p. 257). Both the study conducted by Bayraktar (1997) on primary and secondary school students and the study conducted by Koştaş (1995) on university students showed that religiosity, religious life, religious attitudes, and perceptions of the students were not independent of the family environments.

Religious education in the family environment is of great importance in terms of the two aspects that alienate the child from religion in the later years or abide him/her by the religious values (Günay, 1992, p. 71). The family has great importance in terms of religious formation and it seen that even the origin of religionless traces to childhood ages and parents' religious attitudes and behaviors play a major role in it. 
As a matter of fact, it was found in the study conducted by Bahadir (2012) that the religious suspicion rate $(80 \%)$ was higher in the adolescents who had gone through an inadequate religious education process. In another study (Günay, 1981) conducted on 600 non-believers, it was seen that none of the parents of $67 \%$ of these people were interested in religious life. This and all other studies conducted in our country reveal that the family is an important factor in terms of religious development. Muhammad - the prophet of Islam (pbuh) (632) drawed attention to this responsibility attributed to the family in the hadith "Respect your children and give them good training." Another important factor is the religious socialization process.

\section{Religious Socialization}

Religious development has an individual characteristics in terms of living and feeling, and also has a social qualification in terms of its effects. Religious development, which has a subjective character in terms of individuality, has an objective and observable structure in terms of its social manifestations (Onay, 2004, p. 197). Every individual who is born in a certain social system, is a successor to a certain culture and religious beliefs, traditions, and values in that culture and society at the same time (Günay, 1992, p. 113; Yavuzer, 1998, p. 151). The transfer of social and moral values that will determine the future of the child begins in the first years of life.

The child's social and emotional developments form in parallel with the sensory, physical, and mental development and prepare him/her to enter the community passing through various stages (Cüceloğlu, 1999, p. 355; Kağıtçıbaşı, 1999, p. 119). Therefore, the root of most attitudes arise from the childhood and are generally acquired through direct experience, reinforcement, imitation, and social learning.

Actually, from the moment when human is born, belief is formed in the network of relationships mainly established by his/her own group and social environment. In this sense, according to some researchers, belief development is formed by human's own experiences with the others and the world, and it is influenced by a creator. It is the shaping of human's lives, goals and understandings, beliefs and devotions in the light of being, and value and power. The view of this definition to belief development has a relative and variable structure centered on experience (Osmanoğlu, 2014, p. 181).

\section{Potential Curriculum}

The experiences of the child in his/her early years significantly influence his/her later life (Binbaşioğlu, 2000, p. 60), the emotion-oriented information learned without being criticised during childhood forms the basis of mind-oriented information in the later age (Bılgın \& Selçuk, 1997, p. 70; Çamdıb1, 1994, p. 235). Childhood internal experiments (Armaner, 1978, p. 215) and most of the behaviors acquired over those years shape the individual's personality structure, habit, belief (Selçuk, 1991, p. 13), and standards of judgment in adulthood and influence his/her attitudes and behaviors.

Therefore, attitudes, behaviors, approvals, and appreciations of the family members have great importance in terms of the child's religious thought and behavior development (Şentürk, 1998, p. 55). Having an important influence behind the behavior, belief, attitude, and perceptions of the individual (Özdemır, 1997, p. 121), the family has a strong influence on the developing personality and ego of the child (Kaya, 1997, p. 9). The child, under deep influence of attitudes and behaviors in the family, accepts everything that is given and he/she is prone to everything that goes towards him/her (Bayrakl1, 1997, p. 72; Cole \& Morgan, 2001, p. 207). For this reason, the child's first social behaviors are echoes of his/her parents' sore points.

The potential curriculum is a learning that does not immediately turn into a behavioral change. At certain times, learning takes place without purpose and occurs without being realized by the individual. Individuals can 
learn without realizing it because of the reasons, such as perceptual selectivity, lack of motivation, or distractibility.

In terms of religious education, potential cirriculum is the acceptance of the relationships among family members. Interactions, religious attitudes of family members, and religious life by the children first affect in the dimensions of attitude and knowledge, and then change of this situation into a religious behavior. Reading The Quran, performing prayers, fasting, joy, and excitement in religious holidays, praying on blessed days and at nights by the family members, lead the children to internalize the religious life that they will live in the future.

\section{Religious Identification}

Identification based upon the facts that the individual similarizes himself/herself with another occurs by taking his/her parents as examples for himself/herself in childhood (Kula, 2002, p. 47) and a child enters this process beginning from the moment that he/she is born (Russel, 1996, p. 61; Gövsa, 1998, p. 35). Thus, the behavior of the parents or the person performing their duties sets a strong imitation example for the child. At the beginning, the child is unstable and undecided, but he/she is in the nature that has the power of compliance (Dodurgal1, 1999, p. 91). He/she appropriates the examples he/she sees around for himself/herself partly by the mechanisms of taking after, imitation, and identification.

While the child is accepting the ideals, attitudes, and behaviors of his/her family members through identification, he/she embraces their beliefs, thoughts, and values. Thus, the child learns social values, emotions, and status expectations through his/her experiences with the members of the family. The child accepts his/her adopted parents' ideas and feelings with an effort that does not require much consciousness, and he/she is influenced by their feelings, thoughts, attitudes, and behaviors.

The religion that started by imitating in childhood, gradually develops and deepens into a way of living according to the child's own abilities and the religious atmosphere of the surroundings. The child takes the religious comments, attitudes, and behaviors of the adults as a model and learns as he/she repeats them and make them a habit. Religious beliefs and behaviors are tidied according to the basic dimension of the individuality being formed, and the individual reaches the intrinsic religiosity from the extrinsic religiosity. Thus, the religious life beginning with imitation and identification instills into personality by developing and deepening gradually, according to the religious atmosphere in the surroundings and the individual ability of the child. Consequently, in the survey conducted by K1lavuz (2002), it was seen that there was an important relationship between the age groups and the family members preferred as the identification model, and found that those who wanted to take after their parents and other adults in the family were more than others.

Childhood and adolescence periods are important phases in adopting and passing on the religious beliefs. Adoption of the parents' model behaviours and the religious education given by them are very important in childhood and adolescence periods for the individuals to have an interest in religious life. In childhood period, the most important factor in children's interest in religious life is observing the worshiping parents. The child observing his/her worshiping parents will be able to adopt their religious attitudes and behaviours if he/she identifies with them. In this respect, it can be said that child religiosity is largely a common result of parental religiosity and taking the parents as an example.

\section{Spiritual Awakening}

The parents' religious beliefs, feelings, attitudes, and convictions play a decisive role in the child's religious development (Doğan \& Tosun, 2002, p. 117; Aydın, 2003, p. 105). The involvement of family 
members in religious activities deeply affects children and they are influenced by the religious life they inhale and see at home. While choosing adult's religious behaviors as model for themselves, children learn more and make the behaviours habit as they repeat them. The child learns how to believe, feel, and act with this method, and the learning of moral values through patterning and imprinting on personality continue under the influence of the religious atmosphere as he/she grows up.

Many researches revealed that there was a high correlation between the attitudes of parents and children. The researches comparing the attitudes of parents and children indicate that there is a great similarity between their political and religious attitudes. In this respect, the religious life is born, develops, and matures in the cultural environment where the child grows up and finds his/her personality (Altıntaş, 1981, p. 265). In this context, spiritual awakening in the child is largely dependent on the adult's interest, encouragement, support, and leading (Hökelekl1, 2001, p. 251).

\section{Credulity}

One of the important factors of religious development is that children have high degree of credulity. This situation creates an environment in which the child believes what he/she is said about religion without any question and accepts the things he believes faithfully, too. Credulity in children and devoting to what they believe is a spiritual condition which is peculiar to them. Because the child's feelings are more dominant and more prominent than their thoughts at this period, he/she accepts the belief that is tried to be provided for himself/herself as a natural result of these dominance and prominence.

Credulity is very important in terms of early childhood phase religious development, but the sensitivity to be showed on benefiting from this feature of children is also very important.

The child who is gifted about religion, believes what is said faithfully since he/she is ready to believe without questioning and objection. The child believes not only mentally but also spiritually. Because the child feels himself/herself high-powered and close to God, he tries to build and develop his/her own personal world with his/her beliefs. Credulity and quick devoting which is very important in childhood period religious development are replaced by active and conscious devoting with increasing age.

\section{Sense of Religion and Religious Feelings}

Two of the factors affecting religious development are sense of religion and religious feelings which are origin of belief in individual. The religious feeling in human is defined as the source and capacity that governs the religious interests, desires, and quests that lead to belief. It is known that it has a mutual relationship with other feelings. Moreover, religion is constantly at the source of deep emotional experiences. On that sense, many feelings influence the religious life and perhaps, it is also possible that religion controls the feelings and regulates emotional reactions more powerfully.

Many feelings having an essential place in individual's life are sometimes considered as a source of religious life, and sometimes are approached as feelings relating to the religious life. Depending on the circumstance, one of the feelings, such as religious fear, love, admiration, devotion, endurance, trust, asylum, surrender, desire, hope, thankfulness, avoidance, seeking eternity, praising, tending towards the hereafter, or God is seen as the source of religious feeling or at least one of the important feelings in religious life (Oruç, 2010, p. 76). Developments and improvements also occur in individual's life parallelly to the development of these feelings.

The child's first emotions are affection and trust. Since they are very similar to the feeling of seeking 
shelter in God, which is the source of religious life, they are very important in the child's later religious life. All emotions play a role in the development of religious feeling in human. But the feeling of being in need of affection and compassion in the care of someone else is very important in the religious life of an individual (Kılavuz, 2005, p. 55). At the same time, love feeds other positive feelings, too. Without affection, the feeling of trust and faithfulness does not improve. Researches show that pre-school children want to believe in a friendly God who loves them (Mehmedoğlu, 2005, p. 38). Considering this fact, it is important to make the affection mainstay in teaching of faith in God.

One of the factors in development of religious feeling is the feeling of trust. Confidence arises in the first days of life as a feeling that ensures the life starting from the mother's womb and gains strength by eliminating expectations and requirements. Feeling of trust that prepares the child to perceive himself/herself as a worthwhile entity in the result of satisfying the needs, and plays a significant role in its development shows a significant similarity with the feeling of seeking shelter in God, who is the basis of religious life. In this context, there is a serious affinity between the emergence of religious feeling and the emergence of feeling of trust (Tatar, 2013, p. 22).

In addition to the feeling of trust, the child's feeling of curiosity begins to be seen in this period. Feeling of curiosity is one of the religious feelings and never ends in leading children to the discovery of a supernatural force (Kuşat, 2012, p. 38). Attributing the source of religious feeling directly on inclining to the almighty creator and the feeling of devotion to him/her is also a matter (Yavuz, 1987, p. 96; Onay, 2004, p. 43). Religion extends the individual a "spiritual helping hand" and gives him/her a feeling of "security" that he/she cannot find anywhere else. The individual who feels himself/herself safe can establish more healthy relationships with others as he/she protects himself/herself from many psychological discomforts (Ayten, 2012, p. 141).

\section{Discussion}

It is certain that religious development is a subject that requires multiple, comprehensive, deeply psychological, and sociological assessments. When approached in the context of religious education, it seems possible to rank these processes which affect religious development as feeling of natural religion, feelings of affection and curiosity, need of faithfulness, religious awakening, religious socialization, and family. It is not possible to say that all of these processes on religious development are effective at the same time. The family that an individual is born into and differences, the social interactions, the talents, and possibilities as well as the education taken, social and cultural values have also considerable influence on this process. Moreover, one or more of the dimensions listed here can be the source of religious development for individuals. In this respect, it cannot be said that these processes which are the source of religious development affect the individuals with the same power and motivation. But it can be said that it draws a general framework. On the other hand, this diversity observed in the dimensions of religious development also reveals and nourishes the differences in individual religious experience. This situation leads to the development of religious life through inextricable and interwoven ties.

From a developmental point of view, it should be emphasized that the development of belief is shaped first by parents and family, then by school and friend environment, after that by the individual's self-perception and internal experiences, and finally by religious institutions. In this sense, it is essential that the religion education should be given to the individual who is in every stage of the life by considering his/her developmental 
expectations, competencies, limitations, and other psychosocial elements.

In the common life between the family and religion, the child's religious abilities can easily emerge. Religious awakening in childhood is largely dependent on the adult's interest, encouragement, support, and being model. If a child can first live in a peaceful spiritual environment in the family, a strong religious awakening can be seen in him/her. But, there may be different results depending on the content of the religious life in the family and family structure, the religious interest degree of the family members and the methods and habits followed for religious education.

Religious behaviors, beliefs, and experiences are also part of the culture and they are regularly handed down from one generation to another. Culture and the environment shape the child's religious perspective as well as contributing to other developmental aspects, and influence the awakening and development of religious belief. All observations agree that the influence of relatives is the most obvious factor in the formation of religious attitude. While the child learns to be a social individual, he/she also needs a model that he/she will imitate. Imitation skills also contribute to determining what the child will believe and how to behave in the future.

However, the warm relationship that parents establish with the child is highly influential on him/her in taking their thoughts, behaviors, and beliefs as an example. Again, displaying the religious behaviors in the family is very important for the child to adopt them. Expecting the child to behave in a way that the parents do not do is pedagogically meaningless, and this can cause certain doubts about the value of behaviors in the child's mind.

There must be consistency among family members in religious matters as in other issues. Displaying a common attitude in the religious life by the parents who are considered as role models by the child is very important in terms of both gaining stability by the child in his/her religious life and eliminating the ambiguities that may arise in this issue. The family has a wide range of responsibilities for the child's education, upbringing, preparation for life, religiosity, religious experience, and behavior.

\section{Conclusions}

Belief education in the first years of life is largely the task of the family. It is important for a healthy belief development that parents develop positive feelings of trust, affection, and loyalty in this period and successfully transfer them to religious concepts. In terms of religious development, childhood is a dynamic period of time. For a healthy religious development, it is needed to create an environment in which qualified cognitive stimulants, rich language interactions, positive social-emotional experiences are presented to the child, and the child's independence is supported.

Within the framework of all these processes in our study, the first factor affecting religious development in Turkey is that individuals are inclined and capable to believe in God's existence and oneness. Moreover, it is seen in the basic sources of Islam that giving children religious education is regarded as a religious responsibility for families and institutions. It is possible to evaluate the religious life, the worships, the religious ceremonies, the religious socialization, and interaction processes that take place through religious activities as the factors affecting religious development in Turkey. Although not taken into consideration under a separate heading in this study, it is possible to accept the Koran courses under the presidency of religious affairs, culture of religion, and education of moral courses given at the schools affiliated to the Ministry of National Education (MEB) as well as the communication and interaction processes through mass media as the factors influencing 
the religious development, the religious life, and religiosity in Turkey.

\section{References}

Altıntaş, H. (1981). Çocukluk devresinde ailede din eğitimi (Religious education in the family during childhood). In Türkiye 1 Din Eğitimi Semineri (Turkey 1st Seminar on Religious Education) (pp. 258-270). Ankara: İlahiyat Vakfi.

Armaner, N. (1978). Din eğitiminde psikolojinin önemi (The importance of psychology in religious education). AÜIFD, 23(1), 215-220.

Ay, M. E. (1999). Çocuklarımıza Allah ı nasıl anlatalım? (How can our children tell Allah?) (8th ed.). İstanbul: Timaş.

Ay, M. E. (2001). Ailede ve okulda ideal din eğitimi (Ideal religious education in family and school). İstanbul: Bilge.

Aydın, A. R. (2003). Çocuğun dini kişiliğinin gelişiminde aile faktörü (Family factor in the development of the child's religious personality). EKEV Akademi Dergisi, 15, 105-112.

Ayhan, H. (1995). Ĕgitim bilimine giriş (Introduction to educational science). İstanbul: Şule.

Ayten, A. (2012). Kimlik ve din: İngiltere'deki Türk gençleri üzerine bir araştırma (Identity and religion: A survey of Turkish youth in England). ÇÜIFD, 12(2), 101-119.

Bahadır, A. (2012). Ergenlik döneminde dini şüphe ve tereddütler (Religious doubts and hesitations during adolescence). In H. Hökelekli (Ed.), Gençlik, din ve değerler psikolojisi (Youth, religion, and values psychology). Ankara: Ankara Okulu.

Bayraklı, B. (1997). İslam 'da eğitim (Education in Islam) (5th ed.). İstanbul: Marmara Üniversitesi İlahiyat Vakfi.

Bayraktar, M. F. (1997). İslam ĕgitiminde öğretmen öğrenci münasebetleri (Teacher student relations in Islamic education). İstanbul: Marmara Üniversitesi İlahiyat Vakfi.

Bayraktar, M. M. (2017). Bilişsel gelişim kuramı ve din eğitimi (Cognitive development theory and religious education). Ankara: İlahiyat Yayınları.

Bılgın, B., \& Selçuk, M. (1997). Din öğretimi (Teaching religion) (3rded.). Ankara: Gün.

Bınbaşığlu, C. (2000). Ailede ve okulda eğitim sorunlar (Educational problems in family and school). İstanbul: MEB.

Çamdıbı, H. M. (1994). Şahsiyet terbiyesi ve Gazali (Personality training and Gazali)(2nd ed.). İstanbul: Marmara Üniversitesi İlahiyat Vakfi.

Cole, L., \& Morgan, J., B. (2001). Çocukluk ve gençlik psikolojisi (Childhood and youth psychology). (B. H. Vassaf, Trans.). İstanbul: MEB.

Cüceloğlu, D. (1999). Insan ve davranışı (Man and behavior)(9th ed.). İstanbul: Remzi Kitabevi.

Dodurgalı, A. (1999). Din eğitimi ve ögretiminde ilkeler ve yöntemler (Principles and methods in religious education and teaching). İstanbul: Marmara Üniversitesi İlahiyat Vakfi.

Doğan, R.,\&Tosun, C. (2002). Illköğretim 4. ve 5. sinıflar için din kültürü ve ahlak bilgisi dersi öğretimi (Instruction of religious culture and moral education courses for the 4th and 5th grades of primary education). Ankara: Pegem A.

Eşel, E. (2009). Dini ve mistik deneyimlerin muhtemel bilişşel ve nörobiyolojik düzenekleri (Possible cognitive and neurobiological mechanisms of religious and mystical experiences). Bulletin of Clinical Psychopharmacology, 19, 193-205.

Gövsa, İ. A. (1998). Çocukta duygusal gelişim (Emotional development in child). İstanbul: Hayat.

Günay, Ü. (1981). Türkiye`de dini sosyalleşme (Religious socialization in Turkey). In Türkiye 1 Din Eğitimi Semineri (Turkey 1st Seminar on Religious Education) (pp. 192-199). Ankara: İlahiyat Vakfi.

Günay, Ü. (1992). Eğitim sosyolojisi dersleri (Educational sociology courses). Kayseri: Erciyes Üniversitesi.

Günay, Ü. (2002). Din sosyolojisi (Sociology of religion) (5th ed.). İstanbul: İnsan.

Hökeleklı, H. (2001). Din psikolojisi (Religion psychology). Ankara: Türkiye Diyanet Vakfi.

Hökeleklı, H. (2010). Din psikolojisine giriş (Introduction to psychology of religion). İstanbul: Dem Yayınları.

İmamoğlu, V. (2001). Farklı ortamlarda dini tutumların psiko-sosyal temelleri (Psycho-social foundations of religious attitudes in different settings). In Avrupa Birliğine Giriş Sürecinde Türkiye de Din Eğitimi ve Sorunları Sempozyumu (Symposium on Religious Education and Problems in Turkey in the European Union Entrance Process) (pp. 191-199). Sakarya: Değişim.

Kağıtçıbaşı, Ç. (1999). Yeni insan ve insanlar (New people and people) (10th ed.). Ankara: Evrim.

Kaya, M. (1997). Ailede anne-baba tutumlarının çocuğun kişilik ve benlik gelişimindeki rolü (The role of parental attitudes in the child's personality and self development). OMÜIIFD, 9, 193-203.

Kaya, M. (1998). Din eğitiminde iletişim ve dini tutum (Communication and religious attitudes in religious education). Samsun: Etüt.

Kayıklık, H. (2003). İçerik ve kazanım açısından din psikolojisi (Religion psychology in terms of content and achievement). ÇÜIFD, 3(1), 83-102. 
Kılavuz, M. A. (2002). Ergenlerde özdeşleşme ve din eğitimi (Identification in religions and religious education). In H. Hökelekli (Ed.), Gençlik, din ve değerler psikolojisi (Psychology of youth, religion, and values) (pp.209-254). Ankara: Ankara Okulu.

Kılavuz, M. A. (2005). Anne baba örnek davranışlarının çocukların ve ergenlerin dini kişiliğinin oluşumuna etkileri (The effects of parental behaviors on the formation of the religious personality of children and adolescents). UÜIFD, 14(2), 41-58.

Konuk, Y. (1994). Okul öncesi çocuklarda dini duygunun gelişimi ve eğitimi (The development and education of religious sensation in pre-school children). Ankara: Türkiye Diyanet Vakfi.

Koştaş, M. (1995). Üniversite ögrencilerinde dine bakış (Religious outlook on university students). Ankara: Türkiye Diyanet Vakfi.

Kula, N. (2002). Gençlik döneminde kimlik ve din (Identity and religion in the youth). In H. Hökelekli (Ed.), Din ve değerler psikolojisi (Psychology of religion and values) (pp. 31-70). Ankara: Ankara Okulu.

Kuşat, A. (2012). Bilişsel gelişim açısından din fitrat ilişkisi (Religion relationship in terms of cognitive development). ERUIFD, 2(15), 35-53.

Mehmedoğlu, Y. (2005). Ahlaki ve dini gelişim (Moral and religious development) (3rd ed.). İstanbul: Morpa Kültür.

Okumuşlar, M. (2002). Fitrattan dine (From "Fitrat" to "religion"). Konya: Yediveren.

Onay, A. (2004). Dindarlık, etkileşim ve değişim (Religiosity, interaction, and change). İstanbul: Dem Yayınları.

Oruç, C. (2010). Okul öncesi dönemde dini duygunun kökenleri ve gelişimi (The origins and development of religious sensation in preschool period). Dinbilimleri Akademik Araştırmalar Dergisi, 10(3), 75-96.

Osmanoğlu, C. (2014). Din eğitiminin gelişimsel temeli olarak inanç (Belief in the developmental basis of religious education). Bilimname, 27(2), 177-206.

Özdemır, Ş. (1997). Çocuğun aile eğitiminde hoşgörü (Tolerance of the child in family education). Diyanet İlmi Dergi, 33(1), 121-128.

Peker, H. (2003). Din psikolojisi (Religion psychology). İstanbul: Çamlıca.

Russel, B. (1996). Ë̆itim üzerine (On education). (N. Bezel, Trans.). İstanbul: Say.

Selçuk, M. (1991). Çocuğun eğitiminde dini motifler (Religious motives in the child's education) (2nd ed.). Ankara: Türkiye Diyanet Vakfi.

Şentürk, H. (1998). Çocukta dini ilginin uyanışı ve gelişmesi açısından çevre faktörü (Environmental factor in terms of awakening and development of religious interest in child). Diyanet İlmi Dergi, 24(3), 55-63.

Tatar, Ş. (2013).Okul öncesi eğitim programı din eğitimi ilişkisi (Pre-school education program religion education relationship) (Yüksek lisans, Erzurum Atatürk Üniversitesi).

Usta, M. (2001). Türkiye de yüksek din eğitiminin kurumsallaşma ve ekolleşme sorunları (Problems of institutionalization and schooling of high religious education in Turkey). İstanbul: Marmara Üniversitesi İlahiyat Vakfi.

Yapıcı, A. (2016). MüslümanTürk kültüründe inanç gelişimi (Belief development in Muslim Turkish culture). DEÜIF Dergisi, Din Psikolojisi Özel Sayısı (Religious Psychology Special Issue), 83-113.

Yavuz, K. (1987). Çocukta dinî duygu ve düşüncenin gelişmesi (Development of religious feelings and thinking in the child). Ankara: Diyanet İşleri Başkanlı̆̆ı.

Yavuzer, H. (1998). Çocuk eğitimi el kitabı (Child education handbook) (6th ed.). İstanbul: Remzi Kitabevi.

Yıldırım, B. (1997). Çocuğun şahsiyet gelişiminin yeri ve önemi üzerine bir inceleme (A review of the place and importance of the child's personality development). FÜIFD, 4, 119-136. 